\title{
Biosynthesis of Enduracidin: Origin of Enduracididine and Other Amino Acids
}

\author{
Kazunori Hatano, Ikuo Nogami, Eiji Higashide \\ and Toyokazu KisHi* \\ Applied Microbiology Laboratories, Central Research Division, \\ Takeda Chemical Industries, Ltd., \\ 17-85, Juso-honmachi 2-chome, \\ Yodogawa-ku, Osaka 532, Japan
}

Received November 28, 1983

\begin{abstract}
The biosynthetic origin of the amino acid moieties of enduracidin was investigated by feeding experiments with labeled compounds. Results of the incorporation and the distribution of radioactivity into the antibiotic revealed that glycine, $\mathrm{L}$-serine, $\mathrm{L}$-threonine, $\mathrm{L}$-alanine, $\mathrm{L}$-aspartic acid, L-ornithine and L-citrulline were incorporated into the corresponding amino acid moieties. Unique amino acids, enduracididine and its isomer with an imidazolidine ring, were derived from $\mathrm{L}$ arginine, but not histidine. $\mathrm{K}_{1}$ (4-hydroxyphenylglycine) and $\mathrm{K}_{2}$ (3,5-dichloro- $\mathrm{K}_{1}$ ) moieties were derived from L-tyrosine. ${ }^{36} \mathrm{Cl}$-Sodium chloride was incorporated into the antibiotic in the early stage of fermentation.
\end{abstract}

Enduracidin, a unique peptide antibiotic ${ }^{1 \sim 3)}$ produced by Streptomyces fungicidicus No. B5477, shows a strong bactericidal activity against gram-positive bacteria and a growth promoting effect on animals. ${ }^{4)}$ Mizuno et al. ${ }^{5,6)}$ have confirmed the chemical structure, which is composed of 12 kinds of amino acids including 17 amino acid moieties and an unsaturated fatty acid moiety as a side chain (Fig. 1). Among these amino acids, enduracididine $(\alpha(S)$-amino- $\beta-4(R)$-(2-iminoimidazolidinyl)propionic acid, represented as $\left.Y_{1}\right),{ }^{7)}$ alloenduracididine $\quad(\alpha(R)$-amino- $\beta$ - $4(R)$-(2-iminoimidazolidinyl)-propionic acid, represented as $\left.Y_{2}\right)^{7)}$ (these are generically represented as $\mathrm{Y}$ in this paper) and $\mathrm{K}_{2}$ (3,5-dichloro-4hydroxyphenylglycine $)^{2)}$ are new amino acids, and $\mathrm{K}_{1}$ (4-hydroxyphenylglycine) is rare in natural products. The aim of this investigation is to elucidate the biosynthetic origin of these four amino acids in enduracidin by the feeding experiment using radioactive compounds.

\section{MATERIALS AND METHODS}

Microorganism. Streptomyces fungicidicus No. B-5477, strain 71M-141 was used throughout this work.

Media and culture conditions. The seed and fermentation media are shown in Table I. A spore suspension $\left(5 \times 10^{9}\right.$ cells $/ \mathrm{ml}$ ) was prepared from a slant culture grown on glucose asparagine agar at $28^{\circ} \mathrm{C}$ for 10 days. An aliquot $(0.5 \mathrm{ml})$ of the suspension was inoculated into $200-\mathrm{ml}$ Erlenmeyer flasks containing $40 \mathrm{ml}$ of seed medium and incubated at $28^{\circ} \mathrm{C}$ for $48 \mathrm{hr}$. One milliliter of the resultant culture was transferred to the $40-\mathrm{ml}$ fermentation medium. Fermentation was carried out at $30^{\circ} \mathrm{C}$ for 6 days, on a rotary shaker (Gyrotory Model G25, New Brunswick Scientific Co., $200 \mathrm{rpm}$ ) with a ${ }^{14} \mathrm{CO}_{2}$-trapping apparatus. The radioactive compounds $(10 \mu \mathrm{Ci})$ were added to the culture at zero fermentation time unless otherwise mentioned.

Assay of enduracidin. The amount of enduracidin was determined by the paper disk method using Sarcina variabilis IFO 3067 as a test organism. ${ }^{1)}$

Analysis of labeled enduracidin. The labeled enduracidin was isolated from the culture broth by the method of Sugita et al. ${ }^{8)}$ A mixture of radioactive enduracidin (0.2 to

* Present address: Pharmacognosy Laboratories, Central Research Division, Takeda Chemical Industries, Ltd., 1785, Juso-honmachi 2-chome, Yodogawa-ku, Osaka 532, Japan. 


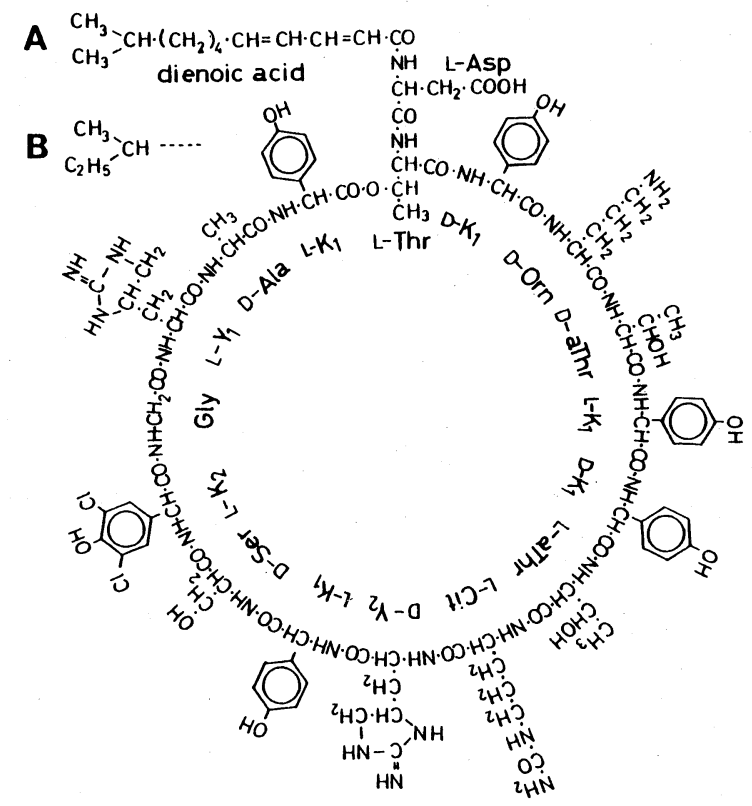

FIG. 1. Structures of Enduracidins A and B.

TABle I. Media fOR Fermentation

\begin{tabular}{|c|c|}
\hline \multicolumn{2}{|l|}{ Seed medium; } \\
\hline Corn starch & $3.0 \%$ \\
\hline Corn steep liquor & 3.5 \\
\hline $\mathrm{CaCO}_{3}$ & 2.0 \\
\hline \multicolumn{2}{|l|}{ Fermentation medium; } \\
\hline \multicolumn{2}{|l|}{ Complex medium } \\
\hline Glucose & $4.0 \%$ \\
\hline Corn starch & 2.0 \\
\hline Corn steep liquor & 2.0 \\
\hline Corn gluten meal & 3.0 \\
\hline $\mathrm{NH}_{4} \mathrm{Cl}$ & 0.5 \\
\hline $\mathrm{NaCl}$ & 1.5 \\
\hline $\mathrm{CaCO}_{3}$ & 1.5 \\
\hline \multicolumn{2}{|c|}{ Chemically defined medium } \\
\hline Corn starch & $3.0 \%$ \\
\hline Sodium glutamate & 0.7 \\
\hline $\mathrm{NaNO}_{3}$ & 0.5 \\
\hline$\left(\mathrm{NH}_{4}\right)_{2} \mathrm{SO}_{4}$ & 0.1 \\
\hline $\mathrm{NaCl}$ & 1.0 \\
\hline $\mathrm{K}_{2} \mathrm{HPO}_{4}$ & 0.1 \\
\hline $\mathrm{MnSO}_{4} \cdot 4 \sim 6 \mathrm{H}_{2} \mathrm{O}$ & 0.0025 \\
\hline $\mathrm{FeSO}_{4} \cdot 7 \mathrm{H}_{2} \mathrm{O}$ & 0.0025 \\
\hline $\mathrm{ZnSO}_{4} \cdot 7 \mathrm{H}_{2} \mathrm{O}$ & 0.0025 \\
\hline $\mathrm{MgSO}_{4} \cdot 7 \mathrm{H}_{2} \mathrm{O}$ & 0.0025 \\
\hline $\mathrm{CuCl}_{2} \cdot 2 \mathrm{H}_{2} \mathrm{O}$ & 0.0025 \\
\hline $\mathrm{CaCO}_{3}$ & 1.0 \\
\hline
\end{tabular}

$1.0 \mathrm{mg}$ ) and non-labeled enduracidin $(5 \mathrm{mg})$ was hydrolyzed with $0.5 \mathrm{ml}$ of $6 \mathrm{~N} \mathrm{HCl}$ at $110^{\circ} \mathrm{C}$ for $18 \mathrm{hr}$ in a sealed tube. The amino acids in the hydrolysate were separated by two-dimensional thin-layer chromatography on cellulose (Avicel SF) with a mixture of $n$-butanol-acetic acid-water $(2: 1: 1, \mathrm{v} / \mathrm{v})$ and a mixture of phenol- $0.5 \mathrm{~N}$ ammonia $(80: 20, \mathrm{v} / \mathrm{v})$ as the first and the second dimensional solvents, respectively, and were detected with $0.02 \%$ ninhydrin solution. Each radioactive spot of amino acid on the thin-layer chromatogram was scraped off from the plate and mixed with a scintillation cocktail for measurement of radioactivity. The incorporation rate of radiøactivity was represented by the percentage of the total radioactivity of labeled compound added. Distribution of radioactivity of individual amino acid moieties in enduracidin was represented as a percentage of the total radioactivity of all amino acid moieties in enduracidin.

Measurement of radioactivity. Radioactivity was measured with a liquid scintillation spectrometer (Aloka, model LSC-502) using an external standard to measure efficiency. An aqueous sample solution $(0.1 \mathrm{ml})$ was mixed with $10 \mathrm{ml}$ of scintillation cocktail containing $12 \mathrm{~g}$ DPO (2,5-diphenyloxazole), $0.3 \mathrm{~g}$ POPOP [1,4-bis(5-phenyloxazolyl)benzene], $100 \mathrm{~g}$ naphthalene, $135 \mathrm{ml}$ toluene, $45 \mathrm{ml} \mathrm{methanol,} \mathrm{and} 720 \mathrm{ml}$ dioxane.

Radiochemicals. ${ }^{14} \mathrm{C}$-Labeled compounds and ${ }^{36} \mathrm{Cl}-$ sodium chloride produced by Radiochemical Centre Amersham (England) were used.

\section{RESULTS}

\section{Incorporation of various labeled compounds into enduracidin}

A typical thin-layer chromatogram of 


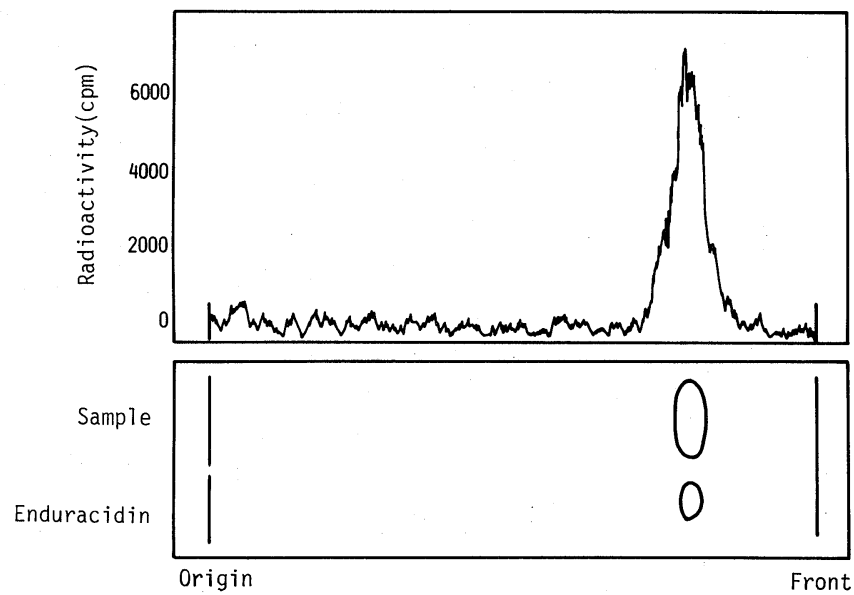

FIG. 2. Thin-layer Chromatogram of ${ }^{14} \mathrm{C}$-Enduracidin Labeled with L-[Guanido- $\left.-{ }^{14} \mathrm{C}\right]$ arginine.

Radioactivity was monitored with a radiochromatogram scanner (Aloka TM-2).

Enduracidin was detected with $0.02 \%$ ninhydrin solution.

TABLE II. INCORPORATION OF RADIOACTIVITY INTO ENDURACIDIN

\begin{tabular}{|c|c|c|c|c|c|c|}
\hline \multicolumn{3}{|c|}{ Compound fed } & \multicolumn{4}{|c|}{ Enduracidin produced } \\
\hline Compound & $\begin{array}{c}\text { Specific } \\
\text { radioactivity } \\
(\mu \mathrm{Ci} / \mu \mathrm{mol})\end{array}$ & $\begin{array}{c}\text { Total } \\
\text { radioactivity } \\
(\mu \mathrm{Ci})\end{array}$ & $\begin{array}{l}\text { Yield } \\
(\mu \mathrm{mol})\end{array}$ & $\begin{array}{c}\text { Specific } \\
\text { radioactivity } \\
(\mu \mathrm{Ci} / \mu \mathrm{mol})\end{array}$ & $\begin{array}{l}\text { Incorporation } \\
\text { rate } \\
(\%)\end{array}$ & $\begin{array}{l}\text { Dilution } \\
\text { factor }^{a}\end{array}$ \\
\hline$\left[\mathrm{U}-{ }^{14} \mathrm{C}\right]$ Glycine & 10 & 10 & 4.58 & $30.3 \times 10^{-3}$ & 1.39 & 330 \\
\hline $\mathrm{L}-\left[\mathrm{U}-{ }^{14} \mathrm{C}\right]$ Alanine & 10 & 10 & 1.69 & 6.5 & 0.11 & 1540 \\
\hline $\mathrm{L}-\left[\mathrm{U}-{ }^{14} \mathrm{C}\right]$ Serine & 10 & 10 & 1.74 & 20.1 & 0.35 & 500 \\
\hline $\mathrm{L}-\left[\mathrm{U}-{ }^{14} \mathrm{C}\right]$ Threonine & 10 & 10 & 3.50 & 164.9 & 5.77 & 60 \\
\hline $\mathrm{L}-\left[\mathrm{U}-{ }^{14} \mathrm{C}\right]$ Aspartic acid & 10 & 125 & 6.44 & 66.0 & 0.34 & 150 \\
\hline $\mathrm{L}-\left[\right.$ Carbamoyl- $\left.{ }^{14} \mathrm{C}\right]$ citrulline & 10 & 10 & 1.84 & 207.1 & 3.81 & 50 \\
\hline $\mathrm{L}-\left[\mathrm{U}-{ }^{14} \mathrm{C}\right]$ Ornithine & 10 & 10 & 1.19 & 321.8 & 3.83 & 30 \\
\hline $\mathrm{L}-\left[\mathrm{U}-{ }^{14} \mathrm{C}\right]$ Arginine & 10 & 10 & 2.16 & 482.4 & 10.42 & 20 \\
\hline L-[Guanido- $\left.-{ }^{14} \mathrm{C}\right]$ arginine & 10 & 10 & 1.84 & 125.5 & 2.31 & 80 \\
\hline L-[Ring- $\left.2-{ }^{14} \mathrm{C}\right]$ histidine & 10 & 10 & 2.65 & 3.0 & 0.08 & 3330 \\
\hline $\mathrm{L}-\left[\mathrm{U}-{ }^{14} \mathrm{C}\right]$ Tyrosine & 10 & 10 & 1.10 & 371.8 & 4.09 & 30 \\
\hline $\mathrm{L}-\left[\mathrm{U}-{ }^{14} \mathrm{C}\right] \mathrm{Phenylalanine}$ & 10 & 10 & 5.08 & 2.0 & 0.10 & 5000 \\
\hline $\mathrm{L}-\left[\mathrm{U}-{ }^{14} \mathrm{C}\right]$ Glutamic acid & 7 & 10 & 2.33 & 6.4 & 0.15 & 1090 \\
\hline$\left[\mathrm{U}-{ }^{14} \mathrm{C}\right] \mathrm{Starch}$ & $27.2^{b}$ & 20 & 5.42 & $1.1^{b}$ & 0.07 & 24730 \\
\hline $\mathrm{D}-\left[\mathrm{U}-{ }^{14} \mathrm{C}\right]$ Glucose & 10 & 10 & 8.50 & 3.5 & 0.30 & 2860 \\
\hline$\left[\mathrm{U}-{ }^{14} \mathrm{C}\right]$ Acetic acid & 10 & 10 & 0.60 & 31.7 & 0.19 & 320 \\
\hline$\left[1{ }^{14} \mathrm{C}\right]$ Propionic acid & 10 & 10 & 7.10 & 2.0 & 0.14 & 5000 \\
\hline$n-\left[1-{ }^{14} \mathrm{C}\right]$ Butyric acid & 10 & 10 & 3.20 & 2.8 & 0.09 & 3570 \\
\hline$\left[\mathrm{U}-{ }^{14} \mathrm{C}\right]$ Oleic acid & 10 & 10 & 3.70 & 4.9 & 0.18 & 2040 \\
\hline
\end{tabular}

Fermentation was carried out at $30^{\circ} \mathrm{C}$ for 6 days using the complex medium.

a Specific radioactivity of ${ }^{14} \mathrm{C}$-labeled compound fed $(\mu \mathrm{Ci} / \mu \mathrm{mol}) /$ specific radioactivity of enduracidin produced $(\mu \mathrm{Ci} / \mu \mathrm{mol})$.

b Specific radioactivity represents as $\mu \mathrm{Ci} / \mathrm{mg}$.

radioactive enduracidin isolated from the cul- pounds into enduracidin are in Table II. ture broth is shown in Fig. 2 and the results of Among the radioactive amino acids tested, the incorporation of various labeled com- glycine, threonine, tyrosine, and ornithine 
Table III. Distribution of Radioactivity to the Amino Acids Obtained by Hydrolysis

\begin{tabular}{lcccccccccc}
\hline \multicolumn{1}{c}{ Compound fed } & Gly & Ala & Ser & Thr & Asp & Cit & Orn & Y $^{a}$ & $\mathrm{~K}_{1}$ & $\mathrm{~K}_{2}(\%)$ \\
\hline [U-14C]Glycine & 38.4 & 0 & 52.9 & 3.9 & 4.7 & 0 & $<1$ & 0 & 0 & 0 \\
L-[U-14C]Alanine & 1.0 & 17.9 & 1.6 & 19.6 & 8.0 & 5.3 & 12.8 & 32.0 & 1.3 & $<1$ \\
L-[U-14C]Serine & 19.3 & 0 & 60.0 & 20.0 & 0 & 0 & $<1$ & 0 & 0 & 0 \\
L-[U-14C]Threonine & 3.4 & 1.0 & 1.8 & 91.1 & $<1$ & $<1$ & $<1$ & 0 & 0 & 0 \\
L-[U-14C]Aspartic acid & 2.0 & $<1$ & 1.1 & 45.6 & 14.4 & 6.4 & 6.8 & 22.9 & 0 & 0 \\
L-[U-14C]Ornithine & 0 & 0 & 0 & 0 & 0 & 26.8 & 20.0 & 53.5 & 0 & 0 \\
L-[Carbamoyl-14C]citrulline & 0 & 0 & 0 & 3.0 & 0 & 25.0 & 5.3 & 66.7 & 0 & 0 \\
L-[U-14C]Arginine & 0 & 0 & 0 & 1.9 & $<1$ & 17.9 & 18.5 & 60.0 & $<1$ & $<1$ \\
L-[Guanido- ${ }^{14}$ C]arginine & $<1$ & $<1$ & $<1$ & $<1$ & $<1$ & 12.9 & 1.8 & 83.2 & $<1$ & 0 \\
L-[U-14 C]Tyrosine & 0 & 0 & 0 & 0 & 0 & 0 & 0 & $<1$ & 81.8 & 17.9 \\
[ ${ }^{36}$ Cl]Sodium chloride & $<1$ & $<1$ & $<1$ & 0 & $<1$ & $<1$ & $<1$ & $<1$ & $<1$ & 97.9 \\
\hline
\end{tabular}

a Enduracididine and alloenduracididine.

TABLE IV. INCORPORATION OF ${ }^{36} \mathrm{Cl}$-SODIUM ChLORIDE INTO ENDURACIDIN

\begin{tabular}{|c|c|c|c|c|c|c|}
\hline \multirow[b]{2}{*}{ Exp. } & \multicolumn{2}{|c|}{${ }^{36} \mathrm{Cl}-\mathrm{NaCl}$ added } & \multicolumn{4}{|c|}{ Enduracidin produced } \\
\hline & $\begin{array}{c}\text { Specific } \\
\text { radioactivity } \\
(\mu \mathrm{Ci} / \mu \mathrm{mol})\end{array}$ & $\begin{array}{l}\text { Time } \\
(\mathrm{hr})\end{array}$ & $\begin{array}{c}\text { Yield } \\
(\mu \mathrm{mol})\end{array}$ & $\begin{array}{c}\text { Specific } \\
\text { radioactivity } \\
(\mu \mathrm{Ci} / \mu \mathrm{mol})\end{array}$ & $\begin{array}{c}\text { Incorporation } \\
\text { rate } \\
(\%)\end{array}$ & $\begin{array}{l}\text { Dilution } \\
\text { factor }\end{array}$ \\
\hline $\mathrm{I}^{a}$ & 0.001 & 0 & 0.05 & $74.1 \times 10^{-3}$ & 0.08 & $<1$ \\
\hline \multirow{4}{*}{$\mathrm{II}^{b}$} & 193.6 & 0 & 0.20 & $220.6 \times 10^{-3}$ & 0.90 & 880 \\
\hline & 193.6 & 24 & 0.27 & 237.0 & 1.28 & 820 \\
\hline & 193.6 & 48 & 0.29 & 97.2 & 0.56 & 1990 \\
\hline & 193.6 & 72 & 0.20 & 14.7 & 0.06 & 13170 \\
\hline
\end{tabular}

Fermentation was carried out at $30^{\circ} \mathrm{C}$ for 6 days using the chemically defined medium.

${ }^{36} \mathrm{Cl}$-Sodium chloride $(5 \mu \mathrm{Ci})$ was added to the medium.

a The chemically defined medium containing $1 \%$ of $\mathrm{NaCl}(6840 \mu \mathrm{mol})$ was used.

$b$ Sodium chloride was omitted from the medium.

cycle-membered amino acids were efficiently incorporated ( 1.4 to $10.4 \%$ ), but alanine, serine, aspartic acid, histidine, and phenylalanine were hardly incorporated $(0.1$ to $0.4 \%)$. Organic acids, fatty acids, and carbohydrates were also barely incorporated.

\section{Distribution of radioactivity among amino acid moieties}

The distribution of radioactivity among the amino acids obtained from acid hydrolysis of ${ }^{14} \mathrm{C}$-enduracidin is shown in Table III. ${ }^{14} \mathrm{C}$ Ornithine, citrulline, and arginine were incorporated mainly into the $\mathrm{Y}$ moiety and parts of them directly into the ornithine and citrulline moieties. ${ }^{14} \mathrm{C}$-Threonine was incorporated predominantly into the threonine moiety. About 50 and $40 \%$ of ${ }^{14} \mathrm{C}$-glycine incorporated into enduracidin was distributed to the serine and glycine moieties, respectively, and $60 \%$ of ${ }^{14} \mathrm{C}$-serine to the serine moiety and $40 \%$ of the radioactivity to the glycine and threonine moieties. ${ }^{14} \mathrm{C}$-Tyrosine was specifically incorporated into the $\mathrm{K}_{1}$ and $\mathrm{K}_{2}$ moieties and the radioactivity distributed to them was 82 and $18 \%$, respectively. About half the radioactivity of ${ }^{14} \mathrm{C}$-aspartic acid incorporated into the antibiotic was distributed to the threonine moiety and the remaining activity was randomized to other amino acids. ${ }^{14} \mathrm{C}$-Alanine was also distributed widely to the $\mathrm{Y}$, threonine, and other amino acid moieties. 


\section{Incorporation of ${ }^{36} \mathrm{Cl}$-sodium chloride into enduracidin}

As shown in Table IV, when ${ }^{36} \mathrm{Cl}$-sodium chloride was added to the fermentation medium in the presence of sodium chloride, it was hardly incorporated into the antibiotic, but when it was added to the chloride-free chemically defined medium, radioactive sodium chloride was incorporated into enduracidin at the growth phase. The incorporation rate rapidly decreased at the production phase. Almost all incorporated radioactive chloride was distributed to the $\mathrm{K}_{2}$ moiety (Table III).

\section{DISCUSSION}

These studies on the biosynthetic origin of the amino acid moieties of enduracidin indicated that radioactive amino acids such as glycine, alanine, serine, threonine, aspartic acid, citrulline, and ornithine supplied exogenously were incorporated into the corresponding amino acid moieties directly or via their metabolic pathways. We concluded that these common amino acid moieties of enduracidin were biosynthesized through well known metabolic pathways of amino acids as follows: 1) Glycine-serine-threonine pathway; serine $\rightleftharpoons$ glycine $=---$ threonine, 2) Aspartate pathway; threonine $\longleftarrow-.-\angle$ aspartate - --- tricarboxylic acid (TCA) cycle--- $\rightarrow$ glutamate $\rightarrow$ --- ornithine $\longrightarrow$ citrulline, 3) Alanine pathway; alanine $\rightarrow$ pyruvate - acetyl-CoA $\longrightarrow$ TCA cycle --. $\rightarrow$ the same metabolic pathway as that of aspartate.

As shown in Fig. 1, enduracidin has six kinds of D-amino acids: D-alanine, D-serine, Dornithine, D- $\mathrm{K}_{1}, \mathrm{D}-\mathrm{Y}_{2}$, and D-allothreonine. Although the biosynthetic mechanisms for these moieties are unclear, the D-amino acid moieties are probably derived from $\mathrm{L}$-isomers by an enzymatic racemization ${ }^{9)}$ or epimerization $^{10,11)}$ during the biosynthesis of enduracidin, as happens in the case of other knwon peptide antibiotics. ${ }^{12)}$

It is assumed that the biosynthetic origin of enduracididine and its isomer $(\mathrm{Y})$ is arginine or histidine since it has an imidazolidine ring.

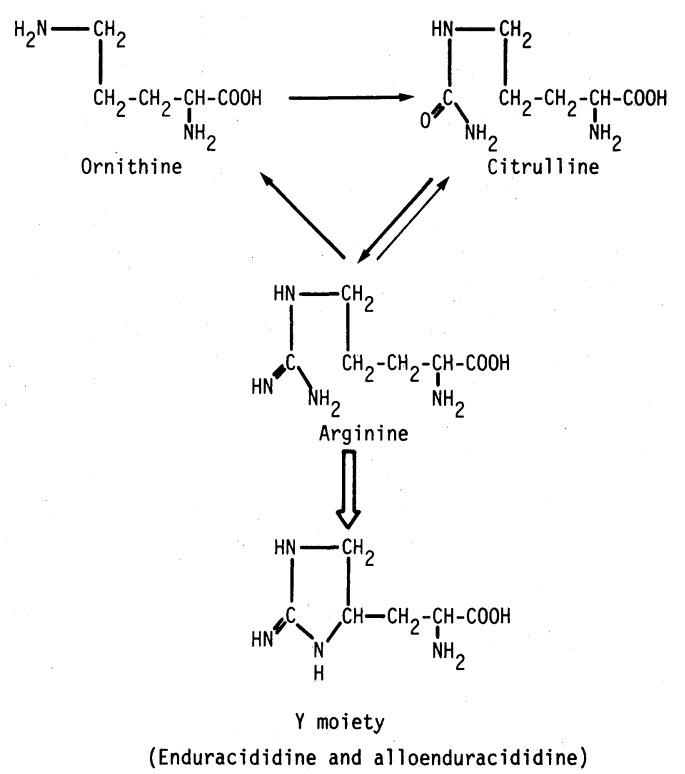

FIG. 3. Proposed Biosynthetic Pathway of Y Moiety (Enduracididine and Alloenduracididine).

The radioisotopic experiments revealed that arginine, ornithine, and citrulline were efficiently incorporated into the Y moiety, but histidine was not incorporated (Table II). This finding suggests that the imidazolidine ring of $\mathrm{Y}$ moiety is formed by the cyclization between the carbon at the $\gamma$-position and the amino group of the guanido moiety of arginine. The proposed biosynthetic pathway of enduracididine and its isomer $(\mathrm{Y})$ is shown in Fig. 3.

Two kinds of aromatic amino acid moieties, $K_{1}$ and $K_{2}$, were derived from tyrosine, but not from phenylalanine (Table II). Tyrosine is probably metabolized to 4-hydroxyphenylglyoxalic acid through a similar pathway as that in nocardicin biosynthesis, ${ }^{13)}$ and converted to 4-hydroxyphenylglycine $\left(\mathrm{K}_{1}\right)$ by a transaminase.

The chlorination of the aromatic ring might occur at an earlier intermediate, probably a metabolite of tyrosine, prior to the formation of the peptide, because the radioactive chloride was efficiently incorporated into enduracidin only at the early stage (zero to $48 \mathrm{hr}$ ) of fermentation at which the antibiotic was not yet being produced. 
Acknowledgment. The authors wish to express their gratitude to Dr. E. Ohmura and Dr. M. Yoneda for their encouragement in this work.

\section{REFERENCES}

1) E. Higashide, K. Hatano, M. Shibata and $K$. Nakazawa, J. Antibiot., 21, 126 (1968).

2) M. Asai, M. Muroi, N. Sugita, H. Kawashima, K. Mizuno and A. Miyake, J. Antibiot., 21, 138 (1968).

3) K. Tsuchiya, M. Kondo, T. Oishi and T. Yamazaki, J. Antibiot., 21, 147 (1968).

4) K. Takeda, T. Kobayashi, T. Kanekiyo and Y. Hamada, Nippon Yoton Kenshi, 11, 280 (1974).

5) K. Mizuno, M. Asai, S. Horii, M. Hori, H. Iwasaki and J. Ueyanagi, Antimicrob. Agent Chemother., 1970, 6 (1971).
6) H. Iwasaki, S. Horii, M. Asai, K. Mizuno, J. Ueyanagi and A. Miyake, Chem. Pharm. Bull., 21, 1184 (1973).

7) S. Horii and Y. Kameda, J. Antibiot., 21, 665 (1968).

8) N. Sugita, K. Naito, M. Asai, T. Suzuki, E. Higashide and K. Mizuno, J. Takeda Res. Lab., 31, 313 (1972).

9) M. Yamada and K. Kurahashi, J. Biochem., 63, 59 (1968).

10) M. Bodanszky and D. Perlman, Nature, 218, 291 (1968).

11) M. Bodanszky and D. Perlman, Science, 163, 352 (1969).

12) K. Kurahashi, "Antibiotics IV, Biosynthesis," ed. by J. W. Corcoran, Springer-Verlag, 1981, pp. 325.

13) J. Hosoda, N. Tani, T. Konomi, S. Ohsawa, H. Aoki and H. Imanaka, Agric. Biol. Chem., 41, 2007 (1977). 